\title{
PENGARUH KONSUMSI MINUMAN ALKOHOL TERHADAP DISFUNGSI EREKSI PADA SOPIR PEROKOK DI TERMINAL ANGKUTAN UMUM KAROMBASAN MANADO
}

\author{
${ }^{1}$ Irene M. Rotinsulu \\ ${ }^{2}$ Grace L. A. Turalaki \\ ${ }^{2}$ Janette M. Rumbajan \\ ${ }^{1}$ Kandidat Skripsi Fakultas Kedokteran Universitas Sam Ratulangi \\ ${ }^{2}$ Bagian Biologi Fakultas Kedokteran Universitas Sam Ratulangi \\ Email: Irenerotinsulu@yahoo.com
}

\begin{abstract}
Consumption of alcoholic beverages in the world led to the deaths of more than 3.3 million people every year, or $5.9 \%$ of all deaths, if not preventable, the number of deaths will increase annually in line with the increasing number of drinkers. A smoker who consumes alcoholic beverages can cause a variety of health problems, one of which is erectile dysfunction. The purpose of this study was to find the effect of consumption of alcoholic beverages to the erectile dysfunction in smoker drivers. This study is an analytic survey with cross sectional approach. The study was conducted in Karombasan Public Transport Terminal from October 2015 to January 2016, with a population of 60 smoker drivers. The sampling of this study uses purposive sampling method to determine which sample meets the criteria. The number of samples obtained is 48 people. Erectile function was assessed using IIEF questionnaire (International Index of Erectile Function). This study showed that from 60 smoker drivers who consumes alcohol beverages, $80 \%$ of them had sustained erectile dysfunction with the degree of dysfunction at most is mild, i.e. $45 \%$. This shows that there are significant effects of alcohol consumption on erectile dysfunction in smoker drivers with a value of $p=0.001(p<0.05)$. It can be concluded that smoker drivers who consumes alcoholic beverages can significantly influence the occurrence of erectile dysfunction.

Keywords: erectile dysfunction, consumption of alcoholic beverages, the driver smokers
\end{abstract}

\begin{abstract}
Abstrak: Konsumsi minuman beralkohol di dunia menyebabkan kematian lebih dari 3,3 juta orang setiap tahunnya atau 5,9\% dari semua kematian, bila tidak dapat dicegah maka jumlah kematian akan bertambah setiap tahunnya seiring bertambahnya jumlah peminum. Seorang perokok yang mengkonsumsi minuman alkohol dapat menyebabkan berbagai gangguan kesehatan pada tubuh salah satunya adalah disfungsi ereksi.Tujuan penelitian ini adalah untuk mengetahui pengaruh konsumsi minuman beralkohol terhadap disfungsi ereksi pada sopir perokok. Penelitian ini merupakan jenis penelitian survei analitik dengan pendekatan cross sectional.Penelitian dilakukan di Terminal Angkutan Umum Karombasan Manado pada bulan Oktober 2015 sampai Januari 2016 dengan jumlah populasi 60 sopir perokok.Penentuan sampel penelitian yaitu yang memenuhi kriteria inklusi dan eksklusi dengan menggunakan teknik purposive sampling dan jumlah sampel yang didapatkan yaitu 48 orang.Fungsi ereksi dapat dinilai dengan menggunakan kuesioner IIEF (International Index of Erectile Function). Hasil Penelitian ini menunjukkan bahwa dari 60 sopir perokok yang mengkonsumsi minuman beralkohol didapatkan $80 \%$ mengalami disfungsi ereksi dengan derajat disfungsi paling banyak terdapat pada disfungsi ringan yaitu sebesar $45 \%$. Ini menunjukkan bahwa terdapat pengaruh konsumsi alkohol terhadap disfungsi ereksi pada sopir perokok dengan nilai $p<0,05$ atau $p=0,001$. Dari hasil penelitian ini dapat disimpulkan bahwa sopir perokok yang
\end{abstract}


mengkonsumsi minuman beralkohol dapat berpengaruh signifikanterhadap terjadinya disfungsi ereksi.

Kata kunci: disfungsi ereksi, konsumsi minuman beralkohol, sopir perokok

Disfungsi ereksi adalah ketidakmampuan organ reproduksi pria untuk melakukan hubungan seksual akibat tidak terjadinya ereksi penis.Sampai saat ini masih banyak kontroversi yang merupakan penyebab ketidakmampuan penis untuk ereksi. Pada dasarnya disebabkan adanya gangguan vaskuler neurogenik dan hormonal. ${ }^{1}$ Seorang pria disebut mengalami disfungsi ereksi jika sering atau selalu tidak mampu mencapai atau mempertahankan ereksi penis untuk melakukan hubungan seksual yang memuaskan. ${ }^{2}$

Masalah disfungsi ereksi merupakan masalah yang dialami oleh banyak pria di dunia.Lebih dari $50 \%$ pria berusia 40 - 70 tahun mengalami disfungsi ereksi dan angka ini naik mendekati $70 \%$ pada usia 70 tahun. ${ }^{3,4}$ Pada tahun 1995 diperkirakan 152 juta pria mengalami disfungsi ereksi dan pada tahun 2025 jumlahnya akan menjadi 322 juta pria seiring dengan pertambahan jumlah manusia di dunia, artinya akan terjadi penambahan sebanyak 170 juta penderita dalam kurun waktu 30 tahun. ${ }^{5} \mathrm{Di}$ Indonesia belum ada data pasti tentang jumlah pria yang mengalami disfungsi ereksi. Diduga sekitar $10-20 \%$ pria menikah mengalami disfungsi ereksi karena berbagai penyebab. ${ }^{6,7}$

Rokok merupakan salah satu pembunuh paling berbahaya di dunia. Rokok adalah hasil olahan tembakau terbungkus yang meliputi kretek dan rokok putih yang dihasilkan dari tanaman Nicotiana Tabacum, Nicotiana Rustica dan spesies lainnya atau sintesisnya yang mengandung nikotin dan tar dengan atau tanpa bahan tambahan. ${ }^{8}$

Menurut WHO, ada 1,3 milyar perokok di dunia dan sepertiganya berasal dari populasi global yang berusia 15 tahun ke atas. Ketergantungan terhadap tembakau sudah menjadi epidemik secara global yang dapat menyebabkan kecacatan, penyakit, produktivitas menurun dan kematian.
Namun demikian, kesadaran untuk berhenti mengkonsumsi tembakau sangat sulit dilakukan karena banyak faktor yang mempengaruhinya antara lain gencarnya industri tembakau untuk mengiklankan produknya tanpa memberikan keterangan yang jelas tentang bahaya tembakau. Indonesia menduduki peringkat ke-4 jumlah perokok terbanyak di dunia dengan jumlah sekitar 141 juta orang.Diperkirakan konsumsi rokok Indonesia setiap tahun mencapai 199 miliar batang rokok. Akibatnya adalah kematian sebanyak 5 juta orang per tahunnya. Bila hal ini tidak dapat dicegah maka jumlah kematian akan meningkat dua kali mendekati 10 juta orang per tahun pada tahun $2020 .^{9}$

Kadang ereksi tidak dapat terjadi bila darah tidak mengalir bebas ke penis.Merokok dapat merusak pembuluh darah, nikotin menyempitkan pembuluh darah arteri yang menuju penis sehingga mengurangi aliran darah dan tekanan darah menuju penis. Efek ini meningkat bersamaan dengan waktu. Masalah ereksi ini merupakan peringatan awal bahwa tembakau telah merusak area lain dari tubuh. $^{9}$

Alkohol adalah cairan bening yang mudah menguap dan mudah bergerak, memiliki bau khas, rasa panas, mudah terbakar dengan memberikan nyala api berwarna biru dan tidak berasap.Alkohol juga adalah depresan yang berfungsi memperlambat refleks, termasuk dalam reaksi pada saat berhubungan seksual. ${ }^{10,11}$ Konsumsi alkohol di dunia menyebabkan kematian lebih dari 3,3 juta orang setiap tahunnya atau 5,9\% dari semua kematian. ${ }^{12}$ Menurut Hasil Riskesdas 2007 di Indonesia prevalensi konsumsi alkohol nasional adalah 4,6\%, pada laki-laki 8,8\%, dan pada perempuan 0,5\% dan Provinsi Sulawesi Utara berada di peringkat dua di atas ratarata konsumsi alkohol nasional dengan prevalensi 17,4\%. Menurut penelitian 
Masters dan Johnson, sekitar 30 - 40\% pria peminum alkohol menunjukkan libido yang menurun dan 40\% menderita kesulitan ereksi, walaupun tidak dijelaskan secara rinci mengenai lamanya konsumsi minuman beralkohol. ${ }^{13,14}$ Hubungan antara konsumsi minuman alkohol dengan disfungsi ereksi pada penduduk Taiwan dari suku aborigin menemukan bahwa 49 \% dari 192 responden memiliki riwayat alkoholik dan 79 responden (84\%) yang alkoholik mengalami disfungsi ereksi. ${ }^{15}$

Masalah seksual pada pria alkoholik mungkin disebabkan oleh pengaruh langsung alkohol terhadap testis.Alkohol dapat menurunkan produksi hormon testosteron sehingga terjadi peningkatan relatif maupun absolut hormon estrogen dan peningkatan presentase testosteron yang terikat ke protein sehingga testosteron bebas yang aktif menjadi berkurang. Akibatnya dorongan seksual menurun atau tertekan. Di samping itu terjadi juga gangguan proses pembentukan spermatozoa. Penggunaan alkohol dalam jangka panjang juga dapat mengganggu fungsi seksual. Akibat lain yang sering terjadi ialah gangguan fungsi hati, gangguan metabolisme neurotransmitter NO (nitric oxide), gangguan saraf tepi, serta kurang darah (anemia). Semua gangguan tersebut pada akhirnya dapat mengganggu fungsi seksual. ${ }^{3,10,16}$

Sopir angkutan merupakan salah satu jenis pekerjaan yang setiap hari terpapar dengan jam kerja yang panjang, sehingga menyebabkan kebanyakan sopir memilih merokok untuk menghabiskan waktu saat berada dalam kemacetan lalu lintas, saat menunggu antrian penumpang dan saat waktu senggang bersama sopir lainnya. Selain menghabiskan waktu dengan merokok, sopir juga mempunyai gaya hidup atau kebiasaan seperti mengkonsumsi minuman beralkohol yang dapat berpengaruh terhadap terjadinya disfungsi ereksi.

Berdasarkan hal-hal di atas penulis tertarik ingin meneliti pengaruh konsumsi minuman alkohol terhadap disfungsi ereksi pada sopir perokok di Terminal Angkutan Umum Karombasan Manado.

\section{METODE PENELITIAN}

Penelitian ini menggunakan desain penelitian survei analitik dengan pendekatan cross sectional. Penelitian ini dilakukan di Terminal Angkutan Umum Karombasan Manado pada bulan Oktober 2015-Januari 2016. Jumlah populasi yaitu 60 sopir perokok. Penentuan sampel penelitian yaitu yang memenuhi kriteria inklusi dan eksklusi dengan menggunakan teknik purposive sampling dan jumlah sampel yang didapatkan yaitu 48 orang.Konsumsi minuman alkohol sebagai variabel bebas sedangkan disfungsi ereksi sebagai variabel terikat. Data dalam penelitian ini diperoleh dari hasil formulir wawancara dan kuesioner yang di isi oleh responden. Analisis univariat dilakukan untuk menjelaskan distribusi frekuensi dari variabel yang diteliti yaitu konsunsumsi minuman alkohol dan disfungsi ereksi. Untuk mengetahui pengaruh variabel bebas terhadap variabel terikat dengan menggunakan Chi-Square.

\section{HASIL PENELITIAN}

\section{Analisis Univariat}

Pada Tabel 1, didapatkan bahwa umur 31 - 40 jauh lebih banyak. Pada Tabel 2, didapatkan bahwa pendidikan SMA jauh lebih banyak. Pada Tabel 3, didapatkan bahwa masa kerja sopir $<10$ tahunjauh lebih banyak. Pada Tabel 4, didapatkan bahwa sebanyak 48 sopir perokok yang mempunyai kebiasaan mengkonsumsi minuman alkohol.

Tabel 1. Distribusi Frekuensi Responden Berdasarkan Umur

\begin{tabular}{lcc}
\hline Umur & $\mathrm{n}$ & $\%$ \\
\hline$<20$ & 5 & 8.3 \\
$21-30$ & 17 & 28.3 \\
$31-40$ & 38 & 63.3 \\
Total & 60 & 100.0 \\
\hline
\end{tabular}


Rotinsulu, Turalaki, Rumbajan: Pengaruh konsumsi minuman...

Tabel 2. Distribusi Frekuensi Responden Berdasarkan Tingkat Pendidikan

\begin{tabular}{ccc}
\hline Pendidikan & $\mathrm{n}$ & $\%$ \\
\hline SD & 8 & 13.3 \\
SMP & 20 & 33.3 \\
SMA & 31 & 51.7 \\
Sarjana & 1 & 1.7 \\
Total & 60 & 100.0 \\
& & \\
\hline
\end{tabular}

Tabel 3. Distribusi Frekuensi Responden Berdasarkan Masa Kerja

\begin{tabular}{ccc}
\hline Masa Kerja & $\mathrm{n}$ & $\%$ \\
\hline$<10$ & 36 & 60.0 \\
$11-20$ & 19 & 31.7 \\
$21-30$ & 5 & 8.3 \\
$31-40$ & 0 & 0 \\
Total & 60 & 100.0 \\
\hline
\end{tabular}

Tabel 4. Distribusi Kategori Konsumsi Minuman Beralkohol

\begin{tabular}{ccc}
\hline Kategori & $\mathrm{n}$ & $\%$ \\
\hline Ya & 48 & 80,0 \\
Tidak & 12 & 20,0 \\
Total & 60 & 100.0 \\
\hline
\end{tabular}

Tabel 5. Distribusi Frekuensi Responden Berdasarkan Jenis Alkohol

\begin{tabular}{lcc}
\hline Jenis Alkohol & $\mathrm{n}$ & $\%$ \\
\hline Cap tikus & 33 & 69 \\
Kesegaran & 9 & 19 \\
Bir & 6 & 12 \\
Total & 48 & 100.0 \\
\hline
\end{tabular}

Pada tabel 5, didapatkan bahwa jenis minuman cap tikus yang paling banyak di konsumsi oleh sopir perokok di Terminal Angkutan Umum Karombasan Manado.

Pada Tabel 6, didapatkan bahwa jumlah gelas alkohol yang paling banyak dikonsumsi oleh sopir perokok adalah $<1$ sloki.

Pada Tabel 7, didapatkan bahwa sopir perokok yang mengkonsumsi minuman alkohol sebanyak 48 orang yang mengalami disfungsi ereksi.
Tabel 6. Distribusi Frekuensi Responden Berdasarkan Jumlah Gelas Alkohol

\begin{tabular}{lcc}
\hline $\begin{array}{l}\text { Jumlah Gelas } \\
\text { Alkohol }\end{array}$ & $\mathrm{n}$ & $\%$ \\
\hline$<1$ sloki & 28 & 58 \\
$1-3$ sloki & 11 & 23 \\
$3-5$ sloki & 9 & 19 \\
Total & 48 & 100.0 \\
\hline
\end{tabular}

Tabel 7. Distribusi Kategori Disfungsi Ereksi

\begin{tabular}{lcc}
\hline \multicolumn{1}{c}{ Kategori } & $\mathrm{n}$ & $\%$ \\
\hline Ya & 48 & 80.0 \\
Tidak & 12 & 20.0 \\
Total & 60 & 100.0 \\
\hline
\end{tabular}

\section{Analisis Bivariat}

Pada Tabel 8, didapatkan bahwa Disfungsi ringan jauh lebih banyak pada sopir perokok yang mengkonsumsi minuman beralkohol.

Tabel 8. Distribusi Kategori Derajat Disfungsi Ereksi

\begin{tabular}{lcc}
\hline Kategori & $\mathrm{n}$ & $\%$ \\
\hline $\begin{array}{l}\text { Tidak } \\
\text { disfungsi }\end{array}$ & 12 & 20.0 \\
$\begin{array}{l}\text { Disfungsi } \\
\text { ringan }\end{array}$ & 27 & 45.0 \\
$\begin{array}{l}\text { Disfungsi } \\
\text { sedang-ringan }\end{array}$ & 11 & 18.3 \\
$\begin{array}{l}\text { Disfungsi } \\
\text { sedang }\end{array}$ & 6 & 10.0 \\
$\begin{array}{l}\text { Disfungsi } \\
\text { berat }\end{array}$ & 4 & 6.7 \\
Total & 60 & 100.0 \\
\hline
\end{tabular}

Berdasarkan hasil penelitian ini mengenai analisis bivariat dengan menggunakan Chi-Square didapatkan bahwa nilai $\mathrm{p}=0,001$. Nilai $\mathrm{p}<0,05$ menunjukkan bahwa terdapat pengaruh yang signifikan antara konsumsi minuman alkohol terhadap disfungsi ereksi pada sopir angkutan umum di Terminal Karombasan Manado. 
Tabel 9. Pengaruh Konsumsi Minuman Alkohol Terhadap Disfungsi Ereksi Pada Sopir Perokok Di Terminal Angkutan Umum Karombasan Manado

\begin{tabular}{lcccccccc}
\hline \multirow{2}{*}{$\begin{array}{l}\text { Konsumsi } \\
\text { Alkohol }\end{array}$} & \multicolumn{2}{c}{ Ya } & \multicolumn{2}{c}{ Tidak } & Total & $\%$ & OR & \multirow{2}{*}{ Nilai P } \\
& & & & & & & $(95 \%$ CI $)$ & \\
& $\mathrm{N}$ & $\%$ & $\mathrm{~N}$ & $\%$ & & & & \\
\hline Ya & 43 & 71,7 & 5 & 8,3 & 48 & 80 & 12,040 & \\
Tidak & 5 & 8,3 & 7 & 11,7 & 12 & 20 & $(2,755-$ & 0,001 \\
Total & 48 & 80,0 & 12 & 20,0 & 60 & 100 & $52,611)$ & \\
\hline
\end{tabular}

Berdasarkan hasil analisis uji bivariat dengan menggunakan uji Chi-Square diketahui bahwa variabel bebas yaitu konsumsi minuman alkohol memiliki pengaruh terhadap disfungsi ereksi pada sopir perokok di Terminal Angkutan Umum Karombasan Manado dengan nilai $\mathrm{OR}=12,040$ (95 \% CI: $(2,755$ - 52,611). Hal ini menunjukkan bahwa sopir perokok yang mempunyai kebiasaan mengkonsumsi minuman alkohol mempunyai peluang 12 kali terhadap disfungi ereksi dibandingkan dengan sopir perokok yang tidak mempunyai kebiasaan mengkonsumsi minuman alkohol.

\section{BAHASAN}

\section{Gambaran Karakteristik Responden}

Berdasarkan hasil pengolahan data untuk distribusi frekuensi responden menurut kategori umur pada sopir perokok didapatkan yang paling banyak berada pada kelompok umur 31 - 40 tahun sebanyak $63,3 \%$, yang kedua pada kelompok umur 21 - 30 tahun sebanyak 28,3\%, dan yang terakhir pada kelompok umur $<20$ tahun sebanyak 8,3\%.

Hasil pengolahan data untuk distribusi frekuensi responden menurut kategori tingkat pendidikan pada sopir perokok didapatkan yang paling banyak berada pada pendidikan SMA sebanyak 51,7\%, yang kedua pada pendidikan SMP sebanyak 33,3\%, dan yang ketiga pada pendidikan SD sebanyak 13,3\%, dan yang terakhir pada pendidikan Sarjana sebanyak 1,7\%.

Hasil pengolahan data untuk distribusi frekuensi responden menurut kategori masa kerja dari sopir perokok di Terminal
Angkutan Umum Karombasan Manado didapatkan yang paling banyak berada pada masa kerja < 10 tahun sebanyak 60,0 \%, yang kedua pada masa kerja 11 - 20 tahun sebanyak 31,7 \%, yang ketiga pada masa kerja 21 - 30 tahun sebanyak 8,3 \% dan yang terakhir pada masa kerja $31-40$ tahun tidak didapatkan atau $0 \%$.

Berdasarkan kriteria inklusi dan kriteria ekslusi yang dipakai dalam pengambilan sampel diketahui bahwa dalam penelitian ini seluruh responden telah bersedia menjadi responden, sudah menikah dan tidak memiliki riwayat penyakit, riwayat psikologis dan riwayat konsumsi obat.

2. Gambaran Konsumsi Minuman Alkohol dan Disfungsi Ereksi

a. Konsumsi Minuman Alkohol

Dalam penelitian ini didapatkan bahwa sebagian besar responden yaitu sopir perokok mempunyai kebiasaan konsumsi minuman alkohol sebanyak 48 orang $(80,0 \%)$ dan yang tidak mempunyai kebiasaan konsumsi minuman alkohol sebanyak 12 orang (20,0\%).

Hal yang memungkinkan responden mengkonsumsi minuman beralkohol disebabkan karena faktor keinginan dari responden itu sendiri, seperti untuk mengisi waktu senggang, berada dalam kondisi stres, cemas atau depresi, ingin dikenal sebagai peminum dan lain-lain.Ada juga pengaruh lingkungan yang mempengaruhi kebiasaan responden mengkonsumsi minuman beralkohol seperti faktor pergaulan, faktor anggota keluarga yang mengkonsumsi alkohol, faktor budaya dan lain-lain sebagainya. 
Hasil Riskesdas 2007 menunjukkan bahwa prevalensi nasional ada 4,6 \% yang mengkonsumsi minuman alkohol. Itu berarti masih termasuk banyak orang di dunia yang tidak lepas dari minuman alkohol.

b. Jenis Alkohol

Dalam penelitian ini menggambarkan karakteristik responden menurut kategori jenis alkohol yang dikonsumsi didapatkan bahwa sebagian besar mengkonsumsi cap tikus sebanyak $69 \%$, kesegaran sebanyak $19 \%$, danbir sebanyak $12 \%$.

c. Jumlah Gelas Alkohol

Dalam penelitian ini menggambarkan karakteristik responden menurut kategori jumlah gelas alkohol yang di konsumsi dalam seminggu didapatkan bahwa paling banyak < 1 sloki sebanyak $58 \%, 1$ - 3 sloki sebanyak $23 \%$, dan 1 - 5 sloki sebanyak $19 \%$.

\section{d. Disfungsi Ereksi}

Dalam penelitian ini didapatkan bahwa sebagian besar sopir perokok di Terminal Angkutan Umum Karombasan Manado mengalami disfungsi ereksi, dimana dari 60 orang responden dalam penelitian ini, sebanyak 48 orang $(80,0 \%)$ mengalami disfungsi ereksi sedangkan 12 orang (20,0 $\%)$ tidak mengalami disfungsi ereksi.

Hal yang memungkinkan responden mengalami disfungsi ereksi disebabkan karena kebiasaan dari responden yang hampir setiap harinya mengkonsumsi minuman alkohol.

Di Indonesia, diduga sekitar $10-20 \%$ pria yang sudah menikah mengalami disfungsi ereksi karena berbagai penyebab. ${ }^{7}$

e. Derajat Disfungsi Ereksi

Dalam penelitian ini didapatkan bahwa sebagian besar sopir perokok di Terminal Angkutan Umum Karombasan Manado mengalami disfungsi ereksi ini dilihat dari kategori total skor fungsi ereksi yaitu 0-6 disfungsi berat, 7-12 disfungsi sedang, 1318 disfungsi sedang - ringan, 19-24 disfungsi ringan, dan 25-30 tidak disfungsi atau normal. Dimana dari 60 orang responden dalam penelitian ini, sebanyak $45 \%$ yang mengalami disfungsi ringan, 20 $\%$ tidak mengalami disfungsi atau normal,
18,3 \% yang mengalami disfungsi sedang ringan, $10 \%$ yang mengalami disfungsi sedang dan 6,7 \% yang mengalami disfungsi berat. Dapat dilihat bahwa dalam penelitian ini yang paling banyak menonjol adalah disfungsi ringan.

3. Pengaruh Konsumsi Minuman Alkohol Terhadap Disfungsi Ereksi Pada Sopir Perokok Di Terminal Angkutan Umum Karombasan Manado

Berdasarkan hasil penelitian ini mengenai analisis bivariat dengan menggunakan Chi-Square didapatkan bahwa nilai $\mathrm{p}=0,001$. Nilai $\mathrm{p}<0,05$ menunjukkan bahwa terdapat pengaruh yang signifikan antara konsumsi minuman alkohol terhadap disfungsi ereksi pada sopir angkutan umum di Terminal Karombasan Manado.

Masalah seksual pada pria alkoholik mungkin disebabkan oleh pengaruh langsung alkohol terhadap testis. Alkohol dapat menurunkan produksi hormon testosteron sehingga terjadi peningkatan relatif maupun absolut hormon estrogen dan peningkatan presentase testosteron yang terikat ke protein sehingga testosteron bebas yang aktif menjadi berkurang. Akibatnya dorongan seksual menurun atau tertekan. Di samping itu terjadi juga gangguan proses pembentukan spermatozoa. Penggunaan alkohol dalam jangka panjang juga dapat mengganggu fungsi seksual pada testis.

Menurut penelitian Masters dan Johnson, sekitar 30 - $40 \%$ pria peminum alkohol menunjukkan libido yang menurun dan $40 \%$ menderita kesulitan ereksi. ${ }^{13,14}$ Penelitian terhadap pria yang minum minuman alkohol menunjukkan bahwa mereka memiliki jumlah testosteron yang lebih rendah dibandingkan pria yang tidak minum. Penelitian juga menyebutkan bahwa berkurangnya testosteron berhubungan dengan jumlah alkohol yang dikonsumsi. Lebih banyak alkohol yang dikonsumsi dan lebih tingginya kadar alkohol dalam darah maka jumlah testosteron menurun sehingga pria tidak mampu mempertahankan ereksi tersebut. ${ }^{17}$ 
bahkan menurut teori setelah berhenti mengkonsumsi alkohol dalam selang waktu berbulan-bulan bahkan bertahun-tahun, hanya $50 \%$ kasus yang fungsi seksualnya kembali normal. ${ }^{14}$

Berdasarkan hasil analisis uji bivariat dengan menggunakan uji Chi-Square diketahui bahwa variabel bebas yaitu konsumsi minuman alkohol memiliki pengaruh terhadap disfungsi ereksi pada sopir perokok di Terminal Angkutan Umum Karombasan Manado dengan nilai OR $=12,040$ (95 \% CI: $(2,755-52,611)$. Hal ini menunjukkan bahwa sopir perokok yang mempunyai kebiasaan mengkonsumsi minuman alkohol mempunyai peluang 12 kali terhadap disfungi ereksi dibandingkan dengan sopir perokok yang tidak mempunyai kebiasaan mengkonsumsi minuman alkohol.

\section{SIMPULAN}

Dari hasil penelitian yang dilakukan di Terminal Angkutan Umum Karombasan Manado dapat ditarik kesimpulan bahwa mengonsumsi minuman alkohol pada sopir perokok mempengaruhi secara signifikan terhadap terjadinya disfungsi ereksi.

\section{SARAN}

Berdasarkan hasil penelitian ini maka saran yang bisa diajukan untuk mencegah dan memperberat terjadinya disfungsi ereksi pada sopir perokok ini adalah sebagai berikut:

1. Sebaiknya sopir dapat mengurangi atau bahkan menghentikan kebiasaan mengkonsumsi minuman alkohol.

2. Sopir dalam penelitian ini termasuk dalam kategori sopir perokok, sehingga diharapkan dapat mengurangi atau bahkan menghentikan kebiasaan merokok.

3. Sebaiknya sopir tidak menghisap rokok pada saat mengendarai kendaraan agar asap rokok tersebut tidak terhirup oleh orang lain yang bisa menjadi perokok pasif.

4. Bila telah didapati gejala dan tanda disfungsi ereksi, sopir sebaiknya dapat melakukan pemeriksaan dan pengobatan ke dokter ahli.

5. Perlu adanya tingkat kesadaran dan pengetahuan tentang kesehatan kerja para sopir agar dapat bermanfaat dalam kehidupan di kemudian hari.

\section{DAFTAR PUSTAKA}

1. Tendean OS, Disfungsi ereksi.2012

2. B Windu S C. Disfungsi seksual - tinjauan fisiologis dan patologis terhadap seksualitas. CV Andi; 2009. Hal 101102

3. Team Dee Publishing. 2010. Kupas Tuntas Impotensi dan Ejakulasi Dini. Cetakan I. Dee Publishing. Yogyakarta.

4. Sherwood, L. 2014. Fisiologi ManusiaDari Sel ke Sistem. Edisi ke-6. EGC. Jakarta.

5. Anonimous. 2014. Disfungsi Ereksi. Online (http://disfungsiereksi.org/disfungsiereksi) diakses pada 24 September 2015.

6. Anonimous. 2014. Penyebab Disfungsi Ereksi. Online (http://disfungsiereksi.org/penyebabdisfungsi-ereksi) diakses pada 24 September 2015.

7. Pangkahila, W. 2014. Seks dan Kualitas Hidup. Kompas Media Nusantara. Jakarta.

8. Keputusan menteri perindustrian dan perdagangan RI. Pedoman cara uji kandungan kadar nikotin dan tar rokok. No 62/ MPP/ Kep/2. 2004

9. Gondodiputro S. Bahaya tembakau dan bentuk-bentuk sediaan tembakau. Unpad: fakultas kedokteran; bagian ikmas. 2007. Bandung.

10.Familia, D. 2010. Seluk-Beluk dan Fakta Disfungsi Seksual Yang Wajib Anda Ketahui. Cetakan I. A Plus Books. Yogyakarta.

11.Anonimous. 2010. Kupas Tuntas Impotensi dan Ejakulasi Dini. Cetakan I. Dee Publishing. Yogyakarta.

12.World Health Organization. 2014. Global status report on alcohol and health 2014. Geneva, Switzerland

13. Mayo Klinik. 2011. Kehilangan LibidoBagaimana Mengatasi Gairah Seks Yang Menurun. Mitra Media.

14.Grover, S., S.K. Mattoo, S. Pendharkar, । 
and V. Kandappan. 2014. Sexual Dysfunction in Patients With Alcohol and Opioid Dependence. Indian Journal of Psychological Medicine; 36(4), .p 355-65.

15.Chao, J.K., M.C. Ma, Y.C. Lin, H.S. Chiang, and T.I. Hwang. 2014. Study on Alcohol Dependence and Factors Related to Erectile Dysfunction Among Aborigines in
Taiwan. American Journal Mens Health.

16.Maiorino, MI, G Bellastella, and $\mathrm{K}$ Esposito. 2014. Lifestyle Modification and Erectile Dysfunction: What Can Be Expected? Asian Journal of Andrology.

17.Hruska KS, Furth PA, Seifer DB.(2000) Environmental factors in infertility. ClinObstet Gynecol; 43:821-9. 